\title{
TEKNIK PEMELIHARAAN BENIH RAJUNGAN (Portunus pelagicus Linn.) DI BALAI BESAR PENGEMBANGAN BUDIDAYA AIR PAYAU JEPARA KABUPATEN JEPARA PROPINSI JAWA TENGAH
}

\section{REARING TECHNIQUE OF BLUE SWIMMING CRAB (Portunus pelagicus Linn.) FRY AT BRACKISH WATER CULTURE DEVELOPMENT CENTRE OF JEPARA, JEPARA REGENCY AND CENTRAL JAVA PROVINCE}

\author{
Juwita Tri Hermawar Yus Tanti dan Laksmi Sulwartiwi
}

Fakultas Perikanan dan Kelautan Universitas Airlangga

Kampus C Mulyorejo - Surabaya, 60115 Telp. 031-5911451

\begin{abstract}
Blue swimming crab is one of fishery commodity for export that still depend from captured, so it will affect population in wild. One of effort to prevent of crab exinction by hatchery advanced. Inhibition of blue swimming crab was survival rate that low, so it was needed case study about rearing technique of blue swimming crab fry.

The aim of this case study was to know directly about rearing technique of blue swimming crab fry and problem that emerged in rearing of blue swimming crab fry. This case study was done at Brackish water Culture Development Center of Jepara, Jepara Regency and Central Java of Province on August 1-30, 2005. Work method which used in case study was descriptive by data collection consisted primary and secondary data. Collection data were done by active participation, interview, observation and study literature.

Fry was produced from brood stock of egg maturation stage III which came from wild. Activities of rearing fry consisted preparing of rearing pond, stocking density, food feeding, monitoring of water qualities, pest and disease control and also harvesting. Water qualities measured were salinity 28-32 ppt and water temperature $29-32^{\circ} \mathrm{C}$. stocking densities were $>100$ inds/lt with survival rates were 1,3-3,8\%. During rearing, fry was given natural feeds such as Chlorella vulgaris, Brachionus plicatilis, Artemia salina, commercial food merk Frippak and grinding shrimp. In this rearing was found red fungi and controlled by using Erythromycin 1ppm. Harvesting was done after fry 18-days age and was done stocking in nursery pond at Brackish water Culture Development Center of Jepara.

Conclusion of this case study were rearing technique of blue swimming crab fry consisted brood stock maintenance, fry rearing system, stocking density, monitoring of water qualities, pest and disease control and also harvesting. Challenge in blue swimming crab with steady system were greatly density, plankton die-off, red fungi and also cannibalism that caused blue swimming crab mortalities.
\end{abstract}

Key words : Portunus pelagicus, benih rajungan, BBPBAP Jepara

\section{Pendahuluan}

Salah satu komoditas perikanan yang saat ini menjadi andalan ekspor non migas adalah rajungan (Portunus pelagicus Linn.). Rajungan merupakan hasil perikanan yang potensial. Di Indonesia rajungan merupakan komoditas perikanan yang diekspor terutama ke negara Amerika, yaitu mencapai 60\% dari total hasil tangkapan rajungan. Rajungan juga diekspor ke berbagai negara dalam bentuk segar yaitu ke Singapura dan Jepang, sedangkan yang dalam bentuk olahan diekspor ke Belanda. Komoditas ini merupakan komoditas ekspor urutan ketiga dalam arti jumlah setelah udang dan ikan (www.dkp.go.id, 2004). Saat ini seluruh kebutuhan ekspor rajungan masih mengandalkan dari hasil tangkapan laut, sehingga dikhawatirkan akan mempengaruhi populasi di alam. Salah satu upaya untuk menghindari kepunahan jenis kepiting ini melalui pengembangan budidaya (Juwana, 2002). Beberapa spesies rajungan yang memiliki nilai ekonomis antara lain Portunus trituberculatus, $P$. gladiator, P. sanguinus, P. hastatoides dan P. pelagicus Linn. (Supriyatna, 1999), sementara yang banyak dipelihara saat ini adalah $P$. pelagicus Linn. dan $P$. trituberculatus.

Pengembangan budidaya rajungan masih jarang dilakukan, berbeda dengan budidaya kepiting bakau yang telah lama dilakukan. Supriyatna (1999) menyatakan bahwa kendala dalam budidaya rajungan 
adalah tingkat kelulushidupan yang masih rendah, yaitu berkisar 4\%-29\%.

Berdasarkan keterangan diatas dapat diketahui bahwa pengetahuan tentang teknik pemeliharaan benih rajungan sangat diperlukan dalam budidaya benih rajungan sehingga dalam usaha pembenihan mampu memproduksi benih dalam jumlah yang cukup, berkesinambungan dan berkualitas unggul.

Tujuan penelitian ini adalah untuk mengetahui secara langsung teknik pemeliharaan benih rajungan serta permasalahan yang dihadapi dalam pemeliharaan benih rajungan di Balai Besar Pengembangan Budidaya Air Payau Jepara, sehingga mahasiswa mampu mengidentifikasi masalah-masalah yang timbul dalam usaha pemeliharaan rajungan.

\section{Materi dan Metode Penelitian}

Tempat dan Waktu

Tempat dan waktu kegiatan studi kasus tentang Teknik Pemeliharaan Benih Rajungan (Portunus pelagicus Linn.) dilakukan Balai Besar Pengembangan Budidaya Air Payau Jepara Kabupaten Jepara Propinsi Jawa Tengah dan dilaksanakan pada tanggal 1-30 Agustus 2005.

\section{Metode Penelitian}

Metode kerja yang digunakan dalam penelitian ini adalah metode deskriptif, yaitu metode yang bertujuan membuat gambaran (deskripsi) secara sistematis, faktual, dan akurat terhadap fakta-fakta dan sifat-sifat populasi atau daerah tertentu (Prijosepoetra, 1997).

\section{Hasil dan Pembahasan}

Sarana yang tersedia dalam pemeliharaan benih rajungan di BBPBAP Jepara antara lain 1 buah bak fiber volume 250 liter untuk pemeliharaan induk, 2 buah bak penetasan artemia yang berbentuk kerucut, 2 buah bak semen volume 6 ton untuk pemeliharaan benih rajungan, 1 buah bak tempat penampungan air laut.

Prasarana yang mendukung dalam kegiatan pemeliharaan benih rajungan di BBPBAP Jepara diantaranya adalah pompa air, pipa aerasi, selang air, gelas ukur, termometer, heater, timbangan analitik dan peralatan panen.

Calon induk yang digunakan dalam kegiatan pembenihan di BBPBAP Jepara berasal dari pedagang pengumpul di sekitar Jepara yang merupakan hasil tangkapan nelayan di laut. Selama ini Jepara menggunakan induk yang berasal dari alam. Alasan penggunaan induk dari alam karena benih yang didapat dari induk ablasi tidak dapat bertahan hidup sampai megalopa, hanya sampai zoea-4. Telur maupun benih yang didapat dari perkawinan secara buatan juga didapatkan hasil yang tidak maksimal, karena kualitas telur dan benih yang dihasilkan kurang baik dibandingkan induk dari alam. Soegiarto dkk. (1979) menyatakan bahwa beberapa faktor yang mempengaruhi jumlah dan kualitas telur antara lain nilai gizi pakan, kualitas air dan tingkat kedewasaan. Di alam yang masih dalam kondisi baik ketiga faktor tersebut dapat terpenuhi dengan baik daripada dengan induk hasil pembesaran.

BBPBAP Jepara mempunyai kendala untuk mendapatkan calon induk pada tahun 2005. Tahuntahun sebelumnya untuk mendapatkan calon induk dapat dengan mudah dan hanya diperlukan waktu kurang lebih 2 hari. Tahun ini diperlukan waktu kurang lebih satu bulan untuk mendapatkan calon induk dan itu perlu pemesanan terlebih dahulu. Satu calon induk mempunyai harga $\mathrm{Rp} 20.000$. Induk rajungan yang dipakai dalam pemeliharaan rajungan di BBPBAP adalah induk matang telur tingkat III dengan ukuran berat tubuh 250 gr dan 200 gr serta mempunyai organ yang lengkap. Induk matang telur tingkat III dapat diketahui dengan adanya warna telur yang sudah berwarna hitam. Penggunaan induk matang telur tingkat III diharapkan agar dapat menetas secepatnya sehingga dalam pemeliharaan induk bertelur tidak terlalu lama. Romimohtarto (1997) mengatakan bahwa induk rajungan yang telurnya telah menghitam akan menetas dalam waktu 1-4 hari setelah dimasukkan ke dalam akuarium.

Pemeliharaan induk bertelur perlu dilakukan. Induk yang digunakan di BBPBAP Jepara berasal dari hasil tangkap yang mungkin sudah terserang penyakit atau luka pada saat penangkapan, sehingga sebelum dipelihara di bak pengeraman, induk rajungan yang baru datang dibersihkan terlebih dahulu dengan air laut steril dan dimasukkan ke dalam ember berisi air laut yang dicampur dengan $50 \mathrm{ppm}$ formalin selama 15 menit dan diaerasi. Isnansetyo dan Kurniastuty (1995) menjelaskan tujuan perendaman formalin untuk membunuh organisme yang tidak diinginkan.

Induk rajungan diangkat setelah 15 menit dan dibersihkan lagi dengan air laut steril kemudian dimasukkan dalam bak fiber volume 250 liter yang telah dipersiapkan dan diberi aerasi. Aerasi diberikan agar dapat meningkatkan konsentrasi oksigen di dalam bak pengeraman induk rajungan. Ghufron (1997) menjelaskan bahwa ikan mudah stres jika oksigen terlarut dalam wadah rendah pada saat suhu $25^{\circ} \mathrm{C}$ atau 
lebih. Kelarutan oksigen di bawah $0,3 \mathrm{mg} / \mathrm{L}$ dapat mematikan ikan bila dibiarkan sampai jangka waktu yang lama. Bak sebelumnya disterilisasikan dengan klorin kemudian dikeringkan agar dapat membunuh mikroorganisme yang tidak diinginkan.

Induk yang digunakan saat studi kasus adalah induk yang mengandung telur kehitaman yang siap menetas. Romimohtarto (1997) menyatakan induk rajungan yang telurnya masih berwarna orange maka telur akan menetas 7 hari lagi. Pemeliharaan induk rajungan bertelur saat studi kasus hanya berlangsung semalam dan keesokan paginya telur telah menetas.

Pemeliharaan benih rajungan di BBPBAP Jepara saat studi kasus menggunakan sistem tetap yaitu pemeliharaan benih rajungan pada bak pemeliharaan benih tanpa pemindahan ke bak lain walaupun pada saat stadia megalopa (H8). Menurut Ruliaty dkk. (2004) pemeliharaan benih rajungan yang dipelihara dengan sistem tetap pada bak pemeliharaan adalah dari H0 hingga H18 (siap tebar/crab-5). Pemeliharaan dengan sistem ini dilakukan agar efisien tempat, waktu, tenaga dan biaya). Kegiatan pemeliharaan benih meliputi persiapan bak pemeliharaan benih, penebaran benih dan padat tebar, pemberian pakan, monitoring kualitas air dan pengendalian hama penyakit.

Bak yang digunakan dalam pemeliharaan benih rajungan adalah 2 buah bak semen volume 6 ton. Bak ditempatkan di ruang terbuka dengan atap dari kaca agar mendapatkan cahaya yang cukup. Bak pemeliharaan benih dilengkapi dengan sistem aerasi dengan jarak aerasi satu dengan yang lainnya adalah 0,5 m. Bak sebagian ditutup dengan terpal yang berfungsi untuk menjaga kestabilan suhu dalam bak pemeliharaan. Suhu air mempunyai pengaruh yang besar terhadap proses pertukaran zat dari makhluk hidup, terutama organisme perairan (Mukti dkk., 2003) Air media pemeliharaan yang digunakan adalah air laut steril dengan salinitas $>31$ ppt yang sebelumnya telah disaring terlebih dahulu dengan menggunakan sand filter pada bak reservoir dan suhu dipertahankan $29-32^{\circ} \mathrm{C}$ menggunakan heater 200 watt 2 buah per bak. Ketinggian air pada bak pemeliharaan yaitu 60 $80 \mathrm{~cm}$. Air media yang digunakan sesuai yang diuraikan oleh Juwana (1999a) dalam Juwana (2002) bahwa suhu optimal berkisar $27-32^{\circ} \mathrm{C}$, salinitas air 28 32 ppt.

Benih terlebih dahulu diseleksi, sebelum benih dipindahkan ke bak pemeliharaan untuk mendapatkan kualitas benih yang sehat. Seleksi benih dilakukan dengan pengambilan dan penghitungan benih yang berenang ke atas mengikuti cahaya (fototaksis positif) dan respon terhadap sentuhan, sedangkan benih yang mengendap di dasar bak tidak diambil. Darsono (1997) menyatakan bahwa zoea yang bersifat planktonis adalah yang menggerombol pada permukaan air. Jumlah benih keseluruhan dari 2 induk adalah 865.062 ekor benih yang selanjutnya ditebar ke bak pemeliharaan.

Benih baru hasil tetasan (zoea-1), dipindahkan ke dalam bak pemeliharaan benih yang telah disiapkan dengan hati hati agar tidak mudah stres. Pengambilan benih rajungan dari bak penetasan dilakukan dengan cara memanfaatkan sifat benih yang tertarik pada sinar. Benih akan berkumpul ditempat yang terkena sinar, kemudian diambil dengan gayung bersama massa air dan ditampung dalam ember yang selanjutnya dari ember penampungan tersebut benih dipindahkan kedalam bak pemeliharaan. Padat penebaran benih pada bak A adalah 589.688 ekor atau 235 ekor/liter sedangkan bak B adalah 275.625 ekor atau 110 ekor/liter. Mardjono dan Arifin (1992) menyatakan bahwa dari hasil uji coba yang dilakukan, disarankan agar dalam pemeliharaan benih rajungan kepadatan yang digunakan tidak lebih dari 100 ekor/liter. Jadi penebaran benih yang dilakukan di kedua bak pemeliharaan tersebut lebih padat dari yang dianjurkan.

Benih rajungan hidup dengan menempel dan tidak melayang-layang di dalam air pada stadia megalopa, sehingga pada stadia megalopa perlu diberikan shelter. Pemasangan shelter berupa waring ini berfungsi untuk memperluas permukaan sehingga dapat mengurangi kanibalisme. Juwana (2002) menjelaskan bahwa kanibalisme yang terjadi selama stadia megalopa dapat dikurangi dengan menyediakan fibre plastik sebagai shelter. Ukuran shelter yang digunakan adalah $0,5 \times$ I m sebanyak 5 buah tiap bak dan dipasang secara vertikal.

Benih rajungan selama masa pemeliharaan diberikan pakan alami berupa phytoplankton dan zooplankton, pakan tambahan dan udang halus. Pemberian pakan tambahan dan udang halus untuk memenuhi nutrisi yang tidak terdapat pada pakan alami. Murtidjo (1992) menyatakan bahwa makanan yang komposisinya dilengkapi dengan makanan tambahan dapat lebih sempurna dalam penyediaan vitamin da mineral, selain efisiensi dalam penggunaan makanan. Makanan alami yang digunakan adalah Rotifer, Chlorella dan Artemia, sedangkan pakan buatan yang diberikan adalah pakan buatan merek Frippak dan udang yang dihaluskan dengan waktu pemberian dan jenis pakan sesuai Tabel 1 . 
Tabel1. Waktu pemberian dan jenis pakan benih rajungan

\begin{tabular}{|c|c|}
\hline Waktu & Jenis Pakan \\
\hline 08.00 & Artemia, Chlorella, Rotifer, Udang \\
12.00 & Pakan Buatan \\
16.00 & Pakan Buatan \\
20.00 & Artemia, Chlorella, Rotifer, Udang \\
24.00 & Pakan Buatan \\
04.00 & Pakan Buatan \\
\hline
\end{tabular}

Chlorella adalah ganggang hijau renik bersel tunggal yang termasuk dalam divisio Thallophyta, sub divisio Algae dan kelas Chlorophyceae. Sel-selnya berdiri sendiri, berbentuk bulat dengan ukuran 3-8. Chlorella tidak berbulu cambuk, sehingga tidak dapat bergerak aktif. Warnanya hijau cerah, terdapat di air tawar dan air asin (Mujiman, 2000). Chorella berfungsi sebagai pakan zooplankton yaitu rotifer dan juga sebagai buffer dalam media pemeliharaan. Pemberian chlorella pada bak pemeliharaan yang baik yaitu dengan mempertahankan chlorella $50.000 \mathrm{sel} / \mathrm{ml}$ sampai benih siap panen (Mardjono dan Arifin, 1992).

BBPBAP Jepara menggunakan Chlorella vulgaris yang telah diendapkan (inokulan sel Chlorella vulgaris) dan diberikan pada stok benih mulai $\mathrm{H} 0$ dan dipertahankan hingga H18 yang siap panen dengan kepadatan dalam bak pemeliharaan $50.000 \mathrm{sel} / \mathrm{ml}$.

Brachionus adalah hewan renik planktonik yang termasuk dalam filum Trochelminthes, kelas Rotatoria (Rotifer). Beberapa jenis yang dikenal antara lain adalah B. plicatilis, B. punctatus, B. angularis. Brachionus yang digunakan di BBPBAP Jepara adalah Brachionus plicatilis.

Ciri khas yang merupakan dasar pemberian nama rotifer adalah terdapatnya suatu bentuk bangunan yang disebut korona. Korona ini bentuknya bulat dan berbulu getar seperti roda, oleh karena itu binatangnya dinamakan rotifera (Mujiman, 2000).

Rotifer dipilih menjadi pakan benih rajungan karena organisme ini memiliki beberapa sifat yang mendukung diantaranya, (1) ukuran relatif kecil, (2) gerakan tidak terlalu cepat, sehingga mudah ditangkap oleh benih rajungan. Pemberian pakan rotifer terbaik yaitu dengan kepadatan 10-15 ekor/ml dalam bak pemeliharaan hingga benih mencapai megalopa (Mardjono dan Arifin, 1992)
BBPBAP Jepara menggunakan pakan alami rotifer karena mudah dibudidayakan secara massal di laboratorium pakan alami. Kebutuhan rotifer untuk pemeliharaan benih rajungan diperoleh dari laboratorium pakan alami dengan kepadatan dalam bak pemeliharaan 10-15 ekor/ml dan diberikan mulai stok awal dari $\mathrm{H} 0$ sampai $\mathrm{H} 9$.

Artemia adalah sejenis udang-udangan primitif yang termasuk dalam filum Arthropoda, kelas Crustacea, sub kelas Branchiopoda, familia Artemiidae. Jenis artemia antara lain Artemia salina dan Artemia tunisia (Mujiman, 2000). Jenis Artemia yang digunakan di BBPBAP Jepara adalah Artemia salina.

Pemberian pakan artemia di BBPBAP Jepara diberikan 2 kali sehari pada pagi dan sore hari dengan kepadatan 5 ekor N/benih/hari dari H1-H2, 7 ekor N/benih/hari dari H3-H4, 10 ekor N/benih/hari dari H5-H6, 19 ekor N/benih/hari dari H7-H9, 20 ekor N/benih/hari dari H10-H15. Pemberian pakan tersebut menggunakan acuan dari Mardjono dkk. (2002) yang menyatakan bahwa hasil ujicoba pemeliharaan benih rajungan untuk restocking nauplius Artemia salina diberikan mulai dari H-1 hingga $\mathrm{H}-15$.

Nauplius artemia yang diberikan berasal dari kista artemia yang ditimbang terlebih dahulu dan didekapsulasi dengan larutan klorin dan dikultur selama 20-24 jam.

Pemeliharaan benih rajungan selain diberikan pakan alami, diberikan pula pakan buatan. Pemberian pakan buatan dimaksudkan untuk melengkapi nutrisi yang tidak terdapat dalam pakan alami baik fitoplankton maupun zooplankton. Selain itu pakan buatan mudah diperoleh. Mujiman (2000) menyatakan bahwa makanan buatan sangat penting untuk disediakan agar dapat tersedia dalam jumlah yang cukup, tepat waktu, berkesinambungan, memenuhi syarat gizi.

Pemeliharaan benih rajungan di BBPBAP Jepara menggunakan pakan buatan merek Frippak yang diberikan 4 kali/hari dengan dosis pakan mulai konsentrasi 0,4 ppm hingga 1 ppm dan kenaikan konsentrasi dilakukan setiap dua hari sebesar 0,1 ppm dengan rincian pakan buatan merek Frippak \#2CD dari H0 - H6, pakan buatan merek Frippak \#2CD PL150 dari H7 H8, pakan buatan merek Frippak PL150 dari H9 - H13 dan pakan buatan merek Frippak PL300 dari H14-H18.

Makanan tambahan yang diberikan saat Praktek Kerja Lapang adalah udang yang dihaluskan menggunakan blender. Pemberian udang halus dilakukan untuk mempercepat pertumbuhan karena 
kandungan nutrisinya yang tinggi. Suriatna (1979) menyatakan bahwa udang mempunyai kandungan protein yang tinggi. Protein mempunyai tiga fungsi bagi tubuh yaitu a) membentuk jaringan baru untuk pertumbuhan, mengganti jaringan yang rusak, maupun bereproduksi, b) berperan dalam pembentukan enzim dan hormon serta pengatur berbagai proses metabolisme di dalam tubuh, c) sebagai zat pembakar.

Udang halus diberikan mulai dari $\mathrm{H} 12$ hingga H18 (benih siap panen) dan diberikan 2 kali/hari pada pagi dan sore hari. Udang sebelum dihaluskan, terlebih dahulu udang dibersihkan untuk diambil dagingnya selanjutnya dicuci dan dihaluskan.

Monitoring kualitas air yang dilakukan dengan penggantian air sebanyak $20 \%$ setiap dua hari sekali untuk menjaga kualitas air media pemeliharaan. Penggantian air dapat menjaga tingkat kelarutan oksigen, mengurangi kandungan bahan organik serta senyawa beracun lainnya (Mardjono dan Arifin, 1992). Media yang digunakan adalah air laut bersih yang telah disterilkan dengan klorin untuk mencegah adanya parasit dari air laut dan telah dinetralkan pada bak penampungan air. Monitoring kualitas air bertujuan agar dapat mengontrol suhu dan salinitas air media pemeliharaan tetap stabil. Monitoring kualitas air dilakukan setiap hari dengan mencatat suhu dan salinitas air media di pagi dan sore hari. Beberapa peneliti seperti Winget dkk. (1976) menyatakan bahwa suhu dan salinitas merupakan faktor utama yang mempengaruhi kelangsungan hidup larva kepiting. Suhu sangat berperan dalam mempercepat metabolisme dan aktifitas organisme. Suhu tinggi akan menyebabkan penurunan kandungan oksigen terlarut karena terjadi peningkatan konsumsi oksigen oleh organisme akibat meningkatnya metabolisme (Mardjono dan Arifin, 1992).

Kadar garam pada air laut media pemeliharaan akan mempengaruhi keseimbangan cairan, koefisien penyerapan, tekanan osmosa dan viskositas (Hill, 1974). Penelitian terhadap pengaruh kombinasi suhu dan salinitas terhadap zoea menunjukkan bahwa kelangsungan hidup tertinggi diperoleh pada suhu antara $25-300^{\circ} \mathrm{C}$ dengan salinitas 30 ppt (Hamid, 1989).

Hasil pengamatan kualitas air menunjukkan bahwa suhu pada kedua bak pemeliharaan berkisar antara $29-31^{\circ} \mathrm{C}$ dan ini merupakan suhu optimal untuk pemeliharaan benih rajungan. Hal ini diperkuat dengan pendapat Ruliaty dkk. (2004) yang menyatakan bahwa suhu air yang optimal untuk pemeliharaan benih rajungan berkisar antara $29-32^{\circ} \mathrm{C}$. Kisaran suhu optimal selama pemeliharaan dipertahankan dengan pemberian heater sehingga suhu air pada media tetap hangat.

Salinitas pada kedua bak berkisar antara 3137 ppt, dimana salinitas tersebut masih dalam ambang batas optimal bagi kehidupan benih rajungan sesuai Ruliaty dkk. (2004) yang menyatakan bahwa salinitas untuk pemeliharaan benih rajungan $>31$ ppt. Salinitas pada sore hari sebelum ganti air mempunyai kisaran nilai lebih tinggi daripada salinitas pada pagi hari setelah ganti air. Hal ini disebabkan karena proses penguapan air sehingga kadar garam pada air media pemeliharaan meningkat.

Hama tidak terdapat pada kedua bak pemeliharaan benih rajungan. Kematian plankton pada H9 menyebabkan endapan kotoran pada dasar bak pemeliharaan menumpuk sehingga timbul adanya jamur merah yang menempel pada dinding bak yang ditemukan pada bak A. Agar jamur merah yang menyerang tidak menimbulkan infeksi pada benih yang dipelihara, maka pengendaliannya dengan pemberian antibiotik berupa Erythromycin sebanyak 1ppm yang diberikan hanya 1 kali setelah terlihat adanya jamur merah. Cara pengendalian hama dan penyakit tersebut belum sesuai yang dianjurkan oleh Mardjono dan Arifin (1994). Pemberian antibiotik seharusnya dilakukan selang seling setiap tiga hari sekali dimaksudkan agar spektrum organisme patogen yang dikendalikan lebih efektif dengan menggunakan antibiotik Erythromycin, herbisida Treflan dan fungisida Furazolidon.

Tahap akhir dari pemeliharaan benih rajungan adalah panen. Panen dilakukan saat benih rajungan berumur 18 hari yang didukung oleh pernyataan Ruliaty dkk. (2004) bahwa panen dilakukan saat benih rajungan berumur 18 hari atau benih siap tebar (crab-5). Peralatan panen yang harus disediakan antara lain ember, gayung, scoop net, mangkok plastik putih dan saringan.

Pemanenan dilakukan dengan cara mengurangi seluruh air media pemeliharaan dengan menggunakan saringan. Pipa pengeluaran pada bak pemeliharaan diberi saringan untuk menampung benih rajungan. Pengumpulan benih dilakukan dengan menggunakan scoop net dan ditampung dalam ember plastik yang diberi aerasi. Penghitungan benih dilakukan dengan menggunakan mangkok plastik putih. Benih rajungan tersebut segera dipindahkan ke dalam tambak pembesaran rajungan yang telah dipersiapkan sebelumnya.

Pertumbuhan dapat didefinisikan sebagai pertambahan ukuran panjang dan berat dalam suatu waktu. Pertumbuhan dipengaruhi oleh beberapa faktor 
umumnya adalah faktor yang sulit dikontrol diantaranya adalah keturunan, seks, umur, parasit dan penyakit. Faktor luar yang mempengaruhi adalah makanan dan suhu media pemeliharaan (Effendie, 1997).

Pengukuran pertumbuhan benih rajungan dilakukan dengan cara mengukur berat dan panjang yang dilakukan setiap tiga hari sekali. Pengukuran berat menggunakan timbangan analitik sedangkan pengukuran panjang menggunakan kertas milimeter yang diamati melalui mikroskop pembesaran 40x. Data pengukuran panjang dan berat benih rajungan terlihat pada Tabel 2 .

Data pengukuran panjang dan berat benih rajungan berdasarkan Tabel 2. diketahui bahwa pertumbuhan panjang benih rajungan mengalami peningkatan tiap harinya, akan tetapi pada $\mathrm{H} 13$ benih rajungan mengalami penurunan pertumbuhan panjang. Berbeda dengan pertumbuhan berat yang mengalami peningkatan terus setiap harinya.

Ruliaty dkk. (2004) menyatakan bahwa pertumbuhan panjang benih rajungan pada stadia zoea mengalami peningkatan pada setiap sub stadia. Besarnya pertambahan panjang tubuh pada setiap sub stadia berbeda-beda. Pada stadia megalopa panjang tubuh benih rajungan mengalami penurunan bila dibandingkan panjang pada stadia zoea. Hal ini disebabkan karena stadia megalopa merupakan stadia peralihan dari bentuk benih menjadi bentuk tubuh seperti rajungan dewasa. Pada proses ini terjadi pemendekan pada daerah posterior benih yang diikuti melebarnya daerah anterior sehingga menjadi karapas.
Setiap kajian yang dilakukan, panjang tubuh benih rajungan pada stadia megalopa lebih pendek bila dibandingkan panjang tubuh pada stadia zoea. Berbeda dengan panjang tubuh benih rajungan yang mengalami pemendekan pada stadia megalopa, berat tubuh benih rajungan justru mengalami kenaikan pada setiap sub stadia maupun pada pengukuran di hari yang berbeda, meskipun pada stadia yang sama (Ruliaty dkk., 2004).

Pertumbuhan panjang dan berat pada bak B lebih tinggi daripada pertumbuhan panjang berat pada bak A. Faktor yang mempengaruhi rendahnya tingkat pertumbuhan panjang dan berat antara lain adalah tingginya tingkat kepadatan yang menyebabkan rendahnya jumlah pakan yang dikonsumsi untuk tiap ekor benih rajungan serta tingginya kompetisi penggunaan oksigen dan ruang gerak. Mukti dkk. (2003) menjelaskan semakin tinggi kepadatan ikan, maka makanan dan oksigen terlarut yang tersedia untuk tiap-tiap individu ikan dapat berkurang dan lebih banyak hasil ekskresi yang terakumulasi di dasar kolam maupun yang terlarut dalam air, sehingga dapat mempengaruhi kondisi lingkungan kolam dan dapat mengganggu kehidupan ikan itu sendiri.

Pertumbuhan panjang berat dengan pemeliharaan sistem tetap mendapatkan kisaran nilai yang lebih rendah dibandingkan dengan pertumbuhan panjang berat pada pemeliharaan benih rajungan dengan sistem modular yang dilakukan pada tahuntahun sebelumnya di BBPBAP Jepara. Beberapa faktor yang mempengaruhi diantaranya adalah padat tebar yang tinggi yaitu lebih dari 100 ekor/liter sehingga menyebabkan terjadinya kanibalisme.

Tabel 2. Data pengukuran panjang dan berat benih rajungan

\begin{tabular}{|c|c|c|c|c|c|c|}
\hline \multirow{2}{*}{ Hari } & \multicolumn{4}{|c|}{ Rata-rata panjang benih $(\mathrm{mm})$} & \multicolumn{2}{|c|}{ Rata-rata berat benih (mg) } \\
\hline & \multicolumn{2}{|c|}{ Bak A } & \multicolumn{2}{|c|}{ Bak B } & Bak A & Bak B \\
\hline H1 & \multicolumn{2}{|c|}{1} & \multicolumn{2}{|c|}{1} & 0,1 & 0,1 \\
\hline $\mathrm{H} 2$ & \multicolumn{2}{|c|}{1,3} & \multicolumn{2}{|c|}{1,3} & 0,14 & 0,14 \\
\hline $\mathrm{H} 4$ & \multicolumn{2}{|c|}{1,8} & \multicolumn{2}{|c|}{1,8} & 0,17 & 0,18 \\
\hline $\mathrm{H} 7$ & \multicolumn{2}{|c|}{2,3} & \multicolumn{2}{|c|}{3} & 0,36 & 0,4 \\
\hline H9 & \multicolumn{2}{|c|}{3} & $\mathrm{~L} 2,3$ & $\mathrm{P} 1,7$ & 0,9 & 1,8 \\
\hline $\mathrm{H} 13$ & $\mathrm{~L} 2,7$ & P 1,9 & L 3,2 & $\mathrm{P} 2,2$ & 4,2 & 5,7 \\
\hline H16 & $\mathrm{L} 3,4$ & P 2,2 & L 4 & P 2,7 & 10,1 & 12,1 \\
\hline
\end{tabular}


Pemeliharaan benih rajungan secara modular, pemindahan pada H8 dilakukan dengan mengatur padat tebar 10 ekor/liter. Padat tebar 10 ekor/liter mampu mencukupi kebutuhan pakan, oksigen dan luas permukaan media untuk tumbuh, sehingga mengurangi terjadinya kanibalisme.

Perbedaan kisaran nilai antara pemeliharaan benih dengan sistem tetap dan sistem modular tidak terlalu tinggi. Pemeliharaan benih dengan sistem tetap mempunyai kelebihan yaitu menghemat tempat/bak pemeliharaan sehingga membutuhkan ruang produksi pemeliharaan yang jauh lebih sedikit bila diproduksi untuk pembenihan rumah tangga skala massal.

Benih rajungan pada bak B pada $\mathrm{H} 9$ sudah $100 \%$ mengalami pergantian ke stadia megalopa, sedangkan bak A belum. Bak A mengalami pergantian ke stadia megalopa $100 \%$ pada H10. Adanya jamur merah yang menempel pada cangkang benih rajungan menyebabkan benih rajungan sulit sekali untuk melakukan moulting, sehingga menyebabkan keterlambatan pergantian ke stadia megalopa. Diduga dengan memindahkan benih rajungan ke air yang baru dan sekaligus menjarangkan kepadatan benih pada saat pemeliharaan, akan membuat benih menjadi lebih sehat sehingga proses moulting rajungan dari stadia 4 ke megalopa tidak terhambat. Alternatif lain seperti yang dijelaskan oleh Kanna (2002) bahwa dapat dilakukan pergantian air setelah menginjak zoea-3 sebanyak 25\%, kemudian ditingkatkan menjadi $30 \%$ untuk zoea-4 dan stadia megalopa sampai stadia crab. Pergantian air diatur sedemikian rupa sehingga salinitasnya pelen-pelen turun hingga 25 ppt pada saat benih mencapai stadia crab.

Derajat kelulushidupan (survival rate) menurut Effendie (1997) yaitu jumlah organisme yang mampu bertahan hidup dalam suatu waktu. Survival rate (SR) benih rajungan dihitung dengan rumus sebagai berikut:

$\mathrm{SR}=\mathrm{Nt} /$ No $\times 100 \%$

Keterangan: $\mathrm{SR}=$ Angka kelulushidupan (ekor)

$\mathrm{Nt}=$ Jumlah rajungan yang hidup saat $\mathrm{t}$ (ekor)

No $=$ Jumlah rajungan yang hidup saat to (ekor)

Penghitungan jumlah benih rajungan dilakukan dengan cara sampling 3 kali ulangan menggunakan gelas ukur $100 \mathrm{ml}$ dengan kondisi bak pemeliharaan tertutup. Pengukuran ini dilakukan mulai H0 hingga $\mathrm{H} 8$ saat larva rajungan masih hidup melayang-layang dan dilakukan penghitungan lagi angka kelulushidupan karena pada stadia megalopa benih rajungan hidup dengan menempel pada dinding ataupun shelter sehingga sampling yang dilakukan tidak dapat mewakili jumlah benih pada bak pemeliharaan. Tidak dilakukan penghitungan tingkat kelulushidupan benih rajungan pada H9 hingga H17. Angka kelulushidupan benih rajungan tertera pada Tabel3.

Berdasarkan Tabel 3. dapat terlihat bahwa benih rajungan pada bak A mempunyai tingkat kelulushidupan yang lebih rendah daripada bak B. Rendahnya tingkat kelulushidupan karena pada dinding kolam ditemukan adanya jamur merah yang menempel, diduga disebabkan karena kematian plankton pada H9. Adanya jamur merah tersebut juga menyebabkan benih rajungan sulit melakukan moulting karena karapas benih rajungan tertutup oleh jamur merah. Endapan kotoran di dasar bak menumpuk menyebabkan kualitas air menurun serta padat tebar lebih dari 100 ekor/liter juga merupakan salah satu penyebab rendahnya tingkat kelulushidupan benih rajungan. Hal ini sesuai yang dikemukakan Ruliaty dkk. (2004) bahwa rendahnya tingkat kelulushidupan dikarenakan oleh beberapa faktor yang mempengaruhi, antara lain padat tebar lebih dari 100 ekor/liter dapat menyebabkan tingginya kompetisi pakan, oksigen dan ruang media pemeliharaan, kanibalisme yang disebabkan oleh kurang pakan.

Tingkat kelulushidupan yang didapatkan dari pemeliharaan benih rajungan dengan sistem tetap mempunyai nilai kisaran yang lebih rendah daripada tingkat kelulushidupan benih rajungan dengan sistem modular (Ruliaty dkk., 2004). Faktor yang mempengaruhinya adalah diduga dengan memindahkan benih rajungan ke air yang baru dan sekaligus menjarangkan kepadatan benih pada saat pemeliharaan, akan membuat benih tercukupi kebutuhan pakan, oksigen, ruang media pemeliharaan untuk bergerak dan tumbuh, mengurangi kanibalisme sehingga menjadi lebih sehat serta proses moulting rajungan dari stadia zoea-4 ke megalopa tidak terhambat.

Hambatan yang sering dihadapi dalam teknik pemeliharaan benih rajungan adalah tidak konsisten terhadap sistem yang digunakan yaitu pada saat uji coba dilakukan dengan sistem modular sedangkan pada pemeliharaan benih sehari-hari menggunakan sistem tetap dan tingginya padat tebar benih rajungan sehingga tingkat kelulushidupan yang didapat rendah hanya berkisar 1,31- 3,8\%. Cara mengatasi hal ini dengan menggunakan sistem modular. Jika dengan 
Tabel 3. Angka kelulushidupan benih rajungan

\begin{tabular}{|c|c|c|c|c|}
\hline \multirow{2}{*}{ Hari } & \multicolumn{2}{|c|}{ Populasi (ekor) } & \multicolumn{2}{c|}{ Angka kelulushidupan (\%) } \\
\cline { 2 - 5 } & Bak A & Bak B & Bak A & 100 \\
\hline H0 & 589688 & 275625 & 100 & 77 \\
H2 & 454060 & 182812 & 66,3 & 38,8 \\
H4 & 369750 & 106875 & 31,4 & 31,4 \\
H6 & 299625 & 86625 & 25,4 & 24,9 \\
H8 & 290062 & 68625 & 24,6 & 3,8 \\
\hline
\end{tabular}

sistem modular tidak efisien terhadap ruang pemeliharaan maka sebaiknya menggunakan sistem tetap dengan padat tebar 100 ekor/liter.

Pemeliharaan benih rajungan ini digunakan untuk bahan uji coba dalam meningkatkan tingkat kelulushidupan benih rajungan serta untuk produksi rajungan di tambak pembesaran. BBPBAP Jepara juga melayani penjualan benih rajungan. Biasanya pembeli datang langsung ke tempat pemeliharaan benih rajungan yang akan digunakan sebagai benih siap tebar pada tambak pembesaran di luar BBPBAP Jepara.

\section{Kesimpulan}

Teknik pemeliharaan benih rajungan (Portunus pelagicus Linn.) adalah sistem tetap yang meliputi tahapan pemeliharaan induk, pemeliharaan benih, penebaran dan padat tebar, monitoring kualitas air, pemberian pakan, hama dan penyakit serta pemanenan. Survival rate yang diperoleh dari pemeliharaan benih rajungan dengan sistem tetap dari $\mathrm{H} 0$ - H18 adalah 1,31 - 3, 8 \%. Pertumbuhan panjang, lebar dan berat yang diperoleh berturut-turut adalah 2,2 - 2,7 mm, 3,4 - 4 mm, 10,1 - 12,1 mg. Kendala dalam pemeliharaan benih rajungan dengan sistem tetap adalah kepadatan yang tinggi, kematian plankton, penyakit jamur merah, serta kanibalisme yang dapat menyebabkan tingginya kematian benih rajungan. Sebaiknya dilakukan penelitian mengenai pemijahan buatan induk rajungan agar didapat induk rajungan matang telur secara kontinyu dan mengenai padat tebar larva yang tepat untuk meningkatkan tingkat kelulushidupan pada pemeliharaan benih rajungan dengan sistem tetap.

\section{Daftar Pustaka}

Darsono, P. 1997. Mating Behavior of the Blue Crab, Calinectes sapidus Rathbun. Majalah Oseana. Vol. XXII No.1. Jakarta. hal 20-32.

Effendie, I. 1997. Biologi Perikanan. Yayasan Pustaka Nustama. Yogyakarta. hal 92-105.

Ghufron, M.H.K.K. 1997. Budidaya Kepiting dan Bandeng di Tambak Sistem Polikultur. Dahara Prize. Semarang. hal 9-39.

Hill, B.J. 1974. Salinity and Temperature Tolerance of Zoea of the Portunidae Crab Scylla serrata. Mar. Biol.

Isnansetyo, A. dan Kurniastuty. 1995. Teknik Kultur Phytoplankton dan Zooplankton. Kanisius. Yogyakarta. 116 hal.

Juwana, S. 2002. Kriteria Optimum untuk Pemeliharan Larva Rajungan (Portunus pelagicus) di Pusat Penelitian dan Pengembangan Oseanologi - LIPI. Neptunus. Majalah Ilmiah Pembangunan dan Pengembangan Kelautan, IX (2) : 75-88.

Juwana, S. dan K. Romimohtarto. 2000. Rajungan; Perikanan, Cara Budidaya dan Menu Masakan. Djambatan. Jakarta. 47 hal.

Kanna, I. 1997. Budidaya Kepiting Bakau; Pembenihan dan Pembesaran. Kanisius. Yogyakarta. 117 hal.

Mardjono, M., L. Ruliaty., R. Prastowo dan Sugeng. 2002. Produksi Benih Portunus Pelagicus untuk Re-stocking. Laporan Tahunan BBPBAP Tahun 2002. Jepara. 26-34.

Mardjono, M. dan M. Arifin. 1992. Pemeliharaan Larva Kepiting Dengan Tingkat Kepadatan Yang Berbeda. Laporan Tahunan BBAP 1992-1993. Jepara. 92-99. 
Mujiman, A. 2000. Makanan Ikan. Penebar Swadaya. Jakarta. hal 37-82.

Mukti, A.T., M. Arief dan W.H. Satyantini. 2003. Diktat Kuliah Dasar-Dasar Akuakultur. Program Studi Budidaya Perairan. Fakultas Kedokteran Hewan Universitas Airlangga. Surabaya. hal 47-53.

Murtidjo, B.A. 1992. Budidaya Udang Galah; Sistem Monokultur. Kanisius. Yogyakarta. hal 7679.

Noor Hamid. 1989. Effects of Temperature and Salinity on the Larvae of Mud Crab Scylla serrata Forskal. UP Visayas Iloilo. $52 \mathrm{p}$.

Prijosepoetro, 1997. Metodologi Ilmiah. Universitas Hang Tuah. Surabaya.

Romimohtarto, K. 1997. Sumberdaya Bentik dari Pulau Pari dan Masalah Masalahnya. Pewarta Oseana (3) : 33-42.

Ruliaty, L., M. Mardjono., R. Prastowo dan Sugeng. 2004. Pemeliharaan Larva Rajungan (Portunus Pelagicus Linn). Laporan Tahunan Kegiatan BBPBAP. Jepara. 41-48.
Soegiarto, A., Toro, V. dan Kinarti, A. 1979. Udang. Proyek Penelitian Potensi Sumberdaya Ekonomi Lembaga Oseanologi Nasional LIPI. Jakarta. 244 hal.

Supriyatna, A. 1999. Pemeliharan Larva Rajungan (Portunus pelagicus) Dengan Waktu Pemberian Pakan Artemia Yang Berbeda. Prossiding Seminar Nasional Puslitbangkan Bekerjasama dengan JICAATA. 173-178.

Suriatna, S. 1979. Kebutuhan Protein dan Asam Amino pada Ikan. Majalah Pertanian 27 (3) : 19-24.

Winget, R.R, C.E. Epifanio, T. Runnel and P. Austin. 1976. Effect of Diet and Temperature on Growth and Mortality of the Blue Crab, Calinectus sapidus maintained in the Resirculating Culture system. Procs. National Shaell Fisheries Association University of Delaware. Vol. 66.

www.dkp.go.id. 2004. Pengamatan Aspek Biologi Rajungan dalam Menunjang Teknik Pembenihannya. http://www.dkp.go.id. 8 hal. 